\title{
Electro-0ptical and Spectral Comparative Study of Some Triazolium Methylids with Biomedical Applications
}

\author{
NICO LETA MELNICIUC PUICA ${ }^{1}$, LILIANA MIHAELA IVAN ${ }^{2 *}$, VALENTINA CLOSCA², DANA ORTANSA DOROHOI² \\ ${ }^{1}$ Alexandru Ioan Cuza University, Faculty of Orthodox Theology, 9 Closca Str., 700066, Iasi, Romania \\ ${ }^{2}$ Alexandru Ioan Cuza University of lasi, Faculty of Physics,11 Carol I Blvd, 700506, Iasi, Romania
}

Some electro-optical characteristics of four carbanion monosubstituted triazolium ylids - precursors in obtaining new heterocycle derivatives with pharmaceutical and industrial applications - were evaluated by spectral and quantum-mechanics studies. The physical properties were established for the optimized structures of triazolium ylids using HyperChem 8. The nature of the interactions solute-solvent in the triazolium ylid solutions was established by correlations between the polarity/polarizability characteristics of the solution components and the wavenumbers of the visible band.

Keywords: quantum mechanics; visible electronic absorption band; 1,2,4 triazolium ylids; solvatochromic study; dipole moment

Organic compounds in which a carbanion is covalently bonded to a positively charged heteroatom (usually nitrogen, phosphorus or sulfur) are called ylids [1]. They are molecules with separated opposite charges, being specific examples of zwitterions. Cycloimmonium ylids [2] include a carbanion bonded to a positively charged nitrogen atom belonging to an azo-heterocycle (such as pyridinium, iso-quinolinium, phtalazinium, pyridazinium, triazolium, etc.). Their carbanion can be mono- or disubstituted (fig. 1).

The R-groups bonded up with the ylid carbon atom are strong electron-withdrawing groups such as $-\mathrm{COC}_{6} \mathrm{H}_{5^{\prime}}$ $\mathrm{COOR},-\mathrm{CN},-\mathrm{CONHC}_{6} \mathrm{H}_{5}$.<smiles></smiles>

a<smiles>[R]C(=[Pt])[N+](=C)C</smiles>

$\mathrm{b}$
Fig. 1. Carbanion monosubstituted (a) and disubstituted (b) cycloimmonium ylids
These are substances of a great interest from both theoretical and practical point of view. Their intramolecular charge transfer (ICT) visible electronic band is very sensitive to the solvent nature, offering information on the intermolecular interactions in solutions [3].

Cycloimmonium ylids have gained an important position among other 1,3-dipolar reactive intermediates as evidence by their selective reactivity toward dipolarophiles offering the most accessible route for the synthesis of heterocyclic compounds [4]. The stable cycloimmonium ylids have interesting applications such as analytical reagents [5], dyes for leather [6] and semi-conducting materials [7]. Using 1,2,4-triazolium ylids as catalyst in the acycloin condensation of formaldehyde mainly ketones are obtained [8] in particular dihydroxyacetone. More than a half of known drugs contain at least one heterocycle compound, aromatic heterocycles playing an important role in pharmaceutical industry. Many 1,2,4-triazolium derivatives exhibit antimicrobial, antifungal, antitumoral, analgesic, anti-inflammatory, psychoactive, anticonvulsant, diuretic, or anti-HIV activity [9]. Nowadays, molecular modeling is used to investigate different types of chemical structures from the simple ones to more complicated structures (proteins, acids, polymers).
Molecular modeling helps us to calculate a number of theoretical parameters of chemical compounds, after the molecular structure is optimized: the bond lengths, the atomic charges, the dipole moment, the polarizability, the main energies (binding energy, heat of formation, total energy), the energies of the HOMO and LUMO levels [10]. Also, the behavior of the molecules can be studied in vacuum or in the presence of a solvent.

A comparative study by physical methods (quantummechanics and spectral) is accomplished for some triazolium methylids with large area of applications especially in biomedical range. The results obtained by quantum mechanics study are compared with spectral data in various dipolar solvents. The spectral characteristics of some 1, 2, 4 triazolium ylids were studied both in binary $[11,12]$ and ternary solutions [13]. By using the statistical cell model of the ternary solutions [14], the interaction energy in molecular pairs of the type ylid -hydroxilic solvent was estimated [15].

The aim of this study is to establish the structural and energetic characteristics of four 1,2,4 triazolium ylids and to analyze the interactions with different solvents.

\section{Experimental part}

\section{Computational and experimental details}

The structures of four carbanion monosubstituted triazolium ylids were analysed with HYPERCHEM 8.0.6. [16], The quantum calculations were performed using PM3 (parametric method number 3 ) which is a semi-empirical method developed by J. . . P. Stewart and published in 1989 [17]. The Polak - Ribiere algorithm was used for the

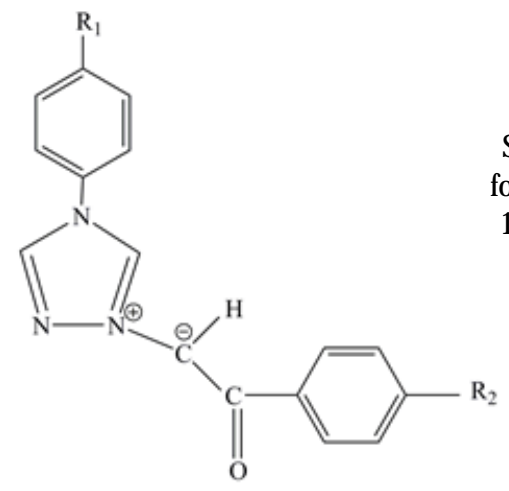

Scheme 1. Structural formula of the studied 1,2,4-triazolium ylids

*email:mihaelaivan2002@yahoo.com 


\begin{tabular}{|l|l|l|}
\hline$R_{1}$ & $R_{2}$ & Name \\
\hline$-\mathrm{H}$ & $-\mathrm{CO}-\mathrm{C}_{6} \mathrm{H}_{5}$ & $4^{\prime}$-phenyl $1,2,4$-triazol-1-ium phenacylid (TI) \\
\hline$-\mathrm{H}$ & $-\mathrm{CO}-\mathrm{C}_{6} \mathrm{H}_{4}-\mathrm{NO}_{2}$ & $4^{\prime}$-phenyl $1,2,4$-triazol-1-ium $4^{\prime \prime}$-nitrophenacylid (T2) \\
\hline$-\mathrm{CH}_{3}(\mathrm{p})$ & $-\mathrm{CO}-\mathrm{C}_{6} \mathrm{H}_{3}$ & $4^{\prime}$-p-methyl-phenyl $1,2,4$-triazol-1-ium phenacylid (T3) \\
\hline$-\mathrm{CH}_{3}(\mathrm{p})$ & $-\mathrm{CO}-\mathrm{C}_{6} \mathrm{H}_{4}-\mathrm{NO}_{2}$ & $4^{\prime}$-p-methyl-phenyl $1,2,4$-triazol-1-ium 4' -nitro phenacylid (T4) \\
\hline
\end{tabular}

Table 1

STRUCTURAL FEATURES OF THE STUDIED 1, 2, 4-TRIAZOLIUM YLIDS

geometry optimization of the studied compounds. Four carbanion monosubstituted 1,2,4-triazolium ylids were synthesised [18] and studied from structural and spectral point of view. The structural features of the studied ylids result from the scheme 1 and table 1.

The electronic spectra of triazolium ylids binary solutions were recorded at a Carl Zeiss Jena UV- Vis Spectrophotometer with data acquisition system.

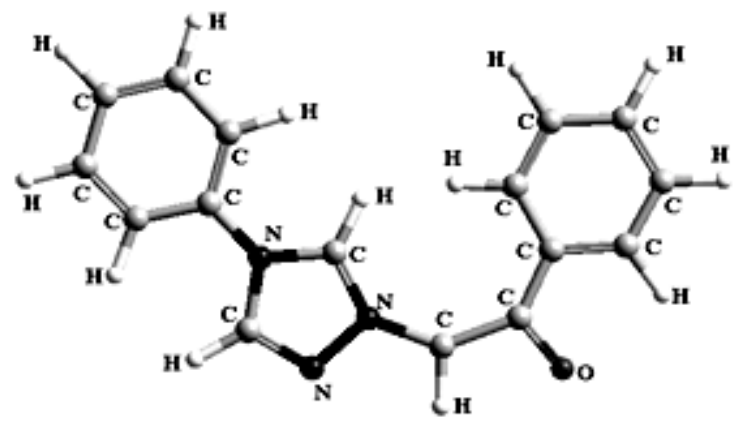

a)

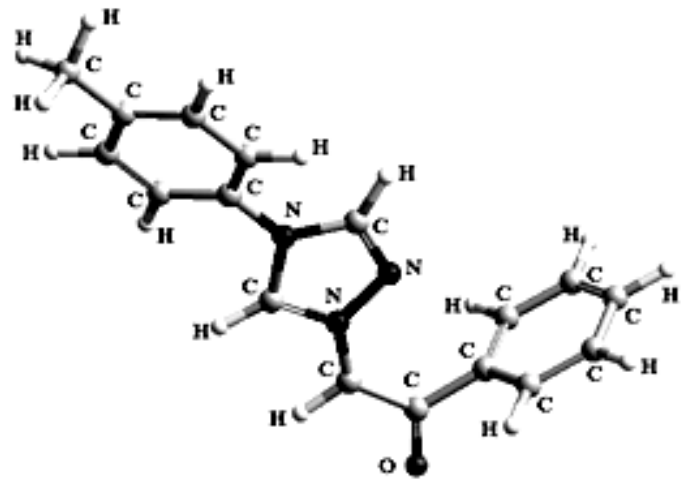

c)

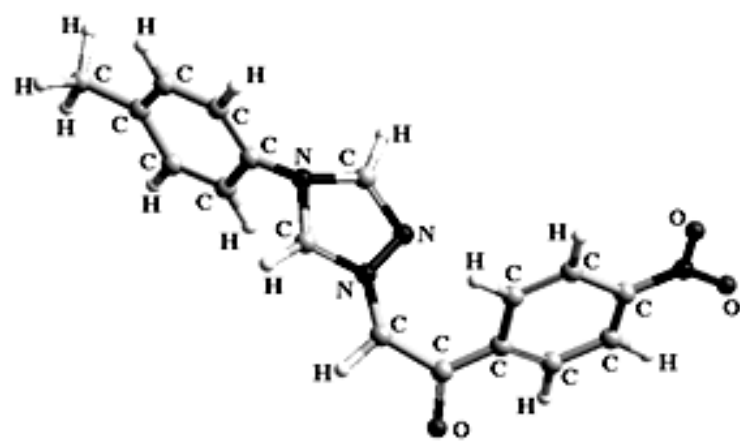

d)

Fig. 2.0ptimized molecular structures of triazolium ylids (a) T1; (b) T2; (c) T3; (d) T4

\begin{tabular}{|c|c|c|c|c|}
\hline Parameter $\quad$ Triazolium ylid & T1 & $\mathrm{T} 2$ & T3 & $\mathrm{T} 4$ \\
\hline Heat of formation ( $\mathrm{kcal} / \mathrm{mol})$ & 106.923 & 98.404 & 83.935 & 75.430 \\
\hline Binding energy $(\mathrm{kcal} / \mathrm{mol})$ & -3703.201 & -3891.736 & -4001.283 & -4189.804 \\
\hline$\Delta \mathrm{E}=\left|\mathrm{E}_{\text {HONO }}-\mathrm{E}_{\text {LUNO }}\right|(\mathrm{eV})$ & 6.848 & 6.835 & 6.820 & 6.957 \\
\hline Hydration energy((kcal/mol) & -8.77 & -13.75 & -7.15 & -12.03 \\
\hline Polarizability $\left(\mathrm{A}^{3}\right)$ & 30.32 & 32.16 & 32.15 & 33.99 \\
\hline $\log P$ & 1.97 & -2.71 & 2.12 & -2.56 \\
\hline Molar Refractivity $\left(\AA^{2}\right)$ & 84 & 89.21 & 88.28 & 93.49 \\
\hline Dipole Moment (D) & 8.25 & 8.82 & 11.42 & 12.62 \\
\hline Volume $\left(A^{3}\right)$ & 789.56 & 852.54 & 836.84 & 897.75 \\
\hline Surface $\left(A^{2}\right)$ & 481.09 & 513.79 & 502.76 & 529.28 \\
\hline Radius $(A)$ & 4.92 & 4.98 & 4.99 & 5.09 \\
\hline
\end{tabular}

Table 2

PHYSICO-CHEMICAL PARAMETERS OF TRIAZOLIUM YLIDS COMPUTED WITH HyperChem

\section{Results and discussions}

computational results

The atomic arrangement obtained after the molecular studied in this paper are listed in table 2.

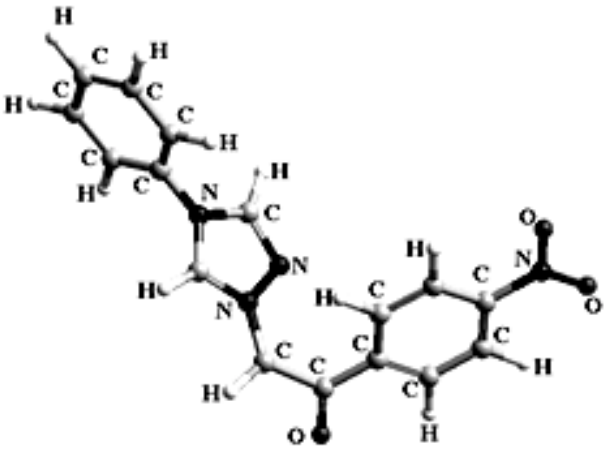

b) 
LogP, can be used to measure the differentiability of a compound in two insoluble phases, being defined as decimal logarithm of the ratio of its concentrations in a mixture of two immiscible phases (one is aqueous and the second solvent is hydrophobic) at equilibrium. When $\log \mathrm{P}$ is negative, the compound is soluble in water, and when it is positive, the compound is lipophilic [20].

The frontier orbitals are playing a very important role in determining the ionization potential, the electron affinity, chemical reactivity, spectroscopic excitation energy or the electrophilicity index [21].

The binding energy and the heat of formation (table 2) show a linear dependence for the studied ylids, illustrated in figure 3.

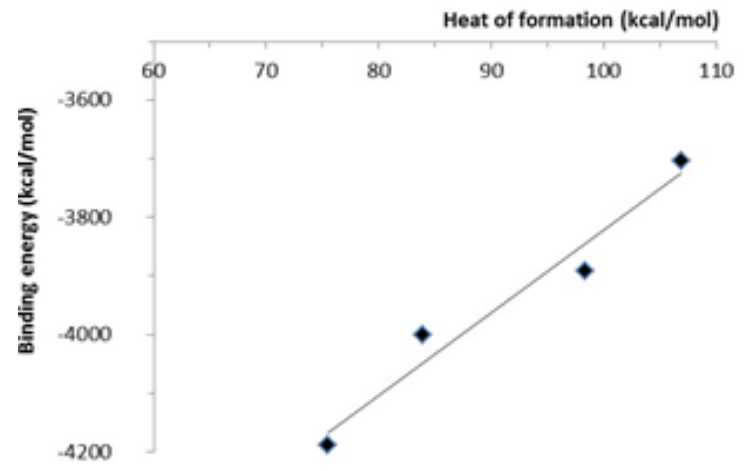

Fig. 3. Binding energy $(\mathrm{kcal} / \mathrm{mol}) \mathrm{vs}$. heat of formation $(\mathrm{kcal} / \mathrm{mol})$

The hydration energy for the studied triazolium ylids is negative, the absolute values being higher for $\mathrm{T} 2$ and $\mathrm{T} 4$ than $\mathrm{T} 1$ and $\mathrm{T} 3$, respectively. As it results from table 2, the ylids T1 and T3 are characterized by positive values of log $P$. Otherwise, T2 and T4 have negative values of $\log P$ and higher values of hydration energy, compared with the first two compounds. Log P is positive for the ylids with benzoyl in the carbanion structure (hydrophobic compounds), and negative for the ylids having p-nitro-benzoyl attached to their carbanion (hydrophilic - $\mathrm{NO}_{2}$ group in the carbanion (from T1 to T2 and T3 to T4, respectively). For the case of ylids with the same carbanion structure, the polarizability increases when the hydrogen atom is replaced by $-\mathrm{CH} 3$ in the pairs T1-T3 and T2-T4, respectively.

Interesting changes are observable when the benzoyl substitute from the ylid carbanion (T1 and T2) is replaced by p-nitro-benzoyl atomic group (in T3 and T4). For the ylids with common heterocycle, (T1-T2 and T3-T4, respectively) this substitution induces comparable variations in energetic parameters (table 3). By inducing changes in the heterocycle structure $(\mathrm{H}$ is replaced by -
$\mathrm{CH}_{3}$, in T1-T3 and T2-T4, respectively), the energetic parameters of the studied ylids are modified in a higher measure compared with the variations induced by structural changes in the carbanion structure in which hydrogen is replaced by - $\mathrm{NO}_{2}$ in pairs T1-T2 and T3-T4, respectively (table 3 ). From table 3 it results that the changes in the carbanion structure (by replacing $\mathrm{H}$ with $\mathrm{NO}_{2}$ in benzoyl substitute, determine modification of the difference $\Delta \mathrm{E}$ from 0.013 to $0.137 \mathrm{eV}$, while by replacing $-\mathrm{H}$ with $-\mathrm{CH}_{3}$ in the heterocycle structure, the same differences vary between 0.028 to $0.122 \mathrm{eV}$. The dipole moment of the studied ylids increases when the substitute benzoyl (from T1 and T3) is replaced by p-nitro-benzoyl (in T2 and T4). Compare T1 with T3 and T2 with T4 respectively in table 2.

\section{Results and discussions}

The low solubility of triazolium ylids in different solvents does not assure the bases for a solvatochromic study in a great number of solvents, but we obtained the visible electronic spectra of these substances recorded in benzene, in some hydroxyl compounds and in dimethylformamide (table 4).

The spectral shifts relative to the position in the wavenumber scale of the visible band in benzene $\Delta v=v$ $-v_{B}$ linearly depend on the ground state dipole moment of the studied ylids, as it results from figures $4 a$ and $4 b$.

The linear dependence is of the type:

$$
\Delta v\left(\mathrm{~cm}^{-1}\right)=A \cdot \mu_{g}(D)+B
$$

The slope $A$ and the cut at origin $B$ are given in table 5 . The values of $A$ and $B$ from relation (1) depend on the solvent nature.

Relation (1) demonstrates that the intermolecular interactions in triazolium ylid solutions are of dipolar nature, based especially on orientation-induction of the ylid zwitterionic molecule in the electric field created by the polar solventmolecules in the centre of the solvation sphere containing the spectrally active molecule. The orientationinduction interactions determine spectral shifts in the visible electronic absorption spectra described by the following formula:

$$
v\left(\mathrm{~cm}^{-1}\right)=v_{0}\left(\mathrm{~cm}^{-1}\right)+C_{1} \frac{\varepsilon-1}{\varepsilon+2}
$$

In relation (2), $v\left(\mathrm{~cm}^{-1}\right)$ is the wavenumber in the maximum of the visible band in the solvent with electric permittivity $\varepsilon ; v_{0}\left(\mathrm{~cm}^{-1}\right)$ is the wavenumber of the maximum of the same band in vacuum (for isolated molecule); and $\mathrm{C}_{1}$ is a constant characteristic of the solute.

\begin{tabular}{|l|l|l|l|l|}
\hline Parameter variation & T1-T2 & T3-T4 & T1-T3 & T2-T4 \\
\hline Heat of formation (kcal/mol) & 8.52 & 8.51 & 22.79 & 22.97 \\
\hline Binding energy(kcal/mol) & 188.54 & 188.52 & 297.08 & 298.07 \\
\hline$\Delta E(\mathrm{eV})$ & 0.013 & 0.137 & 0.028 & 0.122 \\
\hline Hydration energy (kcal/mol) & 1.98 & 1.88 & -1.62 & -1.72 \\
\hline
\end{tabular}

Table 3

CHANGES IN PHYSICO-CHEMICAL PARAMETERS INDUCED BY THE YLID STRUCTURAL MODIFICATIONS

\begin{tabular}{|l|l|l|l|l|l|l|}
\hline Nr. & Solvent & $\varepsilon$ & T1 & T2 & T3 & T4 \\
\hline 1 & Benzene & 2.26 & 25460 & 26110 & 26460 & 26910 \\
\hline 2 & Ethanol & 25.1 & 25620 & 26720 & 26670 & 27630 \\
\hline 3 & Methanol & 33.0 & 25640 & 26810 & 26710 & 27890 \\
\hline 4 & 1,3 Propandiol & 35.0 & 25830 & 26950 & 26910 & 27920 \\
\hline 5 & Dimethylformamide & 38.1 & 25550 & 26690 & 26720 & 28030 \\
\hline 6 & Water & 81.0 & 25970 & 27120 & 27030 & 28210 \\
\hline
\end{tabular}

Table 4

WAVENUMBER IN THE MAXIMUM OF THE VISIBLE ELECTRONIC BAND OF THE STUDIED 1,2,4-TRIAZOLIUM YLIDS IN SOME SOLVENTS 

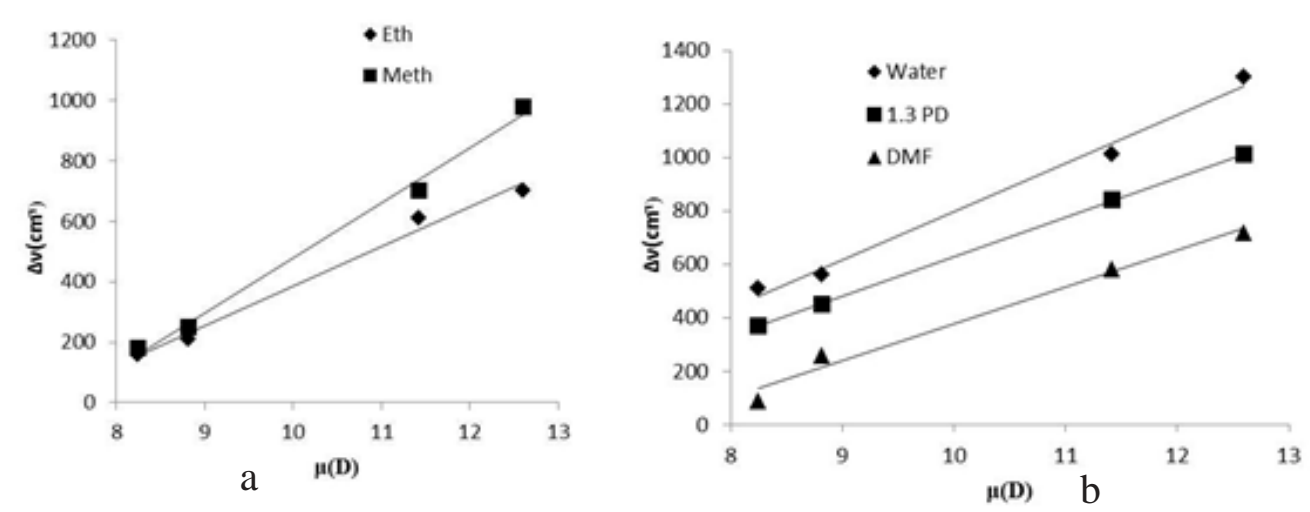

Fig.4. $\Delta v\left(\mathrm{~cm}^{-1}\right)$ vs. $\mu_{\mathrm{g}}(\mathrm{D})$ (a) for Ethanol (Eth) and Methanol (Meth); (b) for Water, 1,3 Propanediol (1,3 PD) and Dimethylformamide (DMF)

Table 5

SOLVENT DIPOLE MOMENT $\mu_{s}(D)$, SLOPE (A), CUT AT ORIGIN (B) AND R²FOR (1) IN VARIOUS SOLVENTS (THE SPECTRAL SHIFT IS MEASURED RELATIVE TO BENZENE)

\begin{tabular}{|l|l|l|l|l|l|}
\hline Nr. & Solvent & $\mu_{s}(D)$ & $A\left(\mathrm{~cm}^{-1} / D\right)$ & $B\left(\mathrm{~cm}^{-1}\right)$ & $R^{2}$ \\
\hline 1 & Methanol & 1.70 & 182.23 & -1344.50 & 0.994 \\
\hline 2 & Ethanol & 1.69 & 131.48 & -930.63 & 0.989 \\
\hline 3 & 1,3 -Propanediol & 2.52 & 147.88 & -815.60 & 0.999 \\
\hline 4 & Dimethylformamide & 3.82 & 180.90 & -1344.50 & 0.994 \\
\hline 5 & Water & 1.85 & 182.23 & -1013.30 & 0.990 \\
\hline
\end{tabular}

In the theories regarding the simple liquids, the coefficient $\mathrm{C}_{1}$ is given by a relation of the type:

$$
C_{1}=\frac{2 \mu_{g}\left(\mu_{g}-\mu_{e} \cos \varphi\right)}{a^{3}}
$$

In formula (3), $\mu$ and $\mu$ are the ylid dipole moments in its ground and excited electronic states; $\varphi$ is the angle between the dipoles; $a$ is the ylid Onsager radius.

The wavenumber in the maximum of the visible electronic absorption band of the studied triazolium ylids linearly depends (fig. 6) on the function:

$$
f(\varepsilon)=\frac{\varepsilon-1}{\varepsilon+2}
$$

The value of the coefficient $C$ can be obtained from the solvatochromic study. The excited state dipole moment can be estimated on the basis of the values of this coefficient, using the values the values of $\mu_{g}$ and $a$ obtained by HyperChem.

The results obtained by statistical methods applied to spectral data contained in table 4 are listed in table 6.

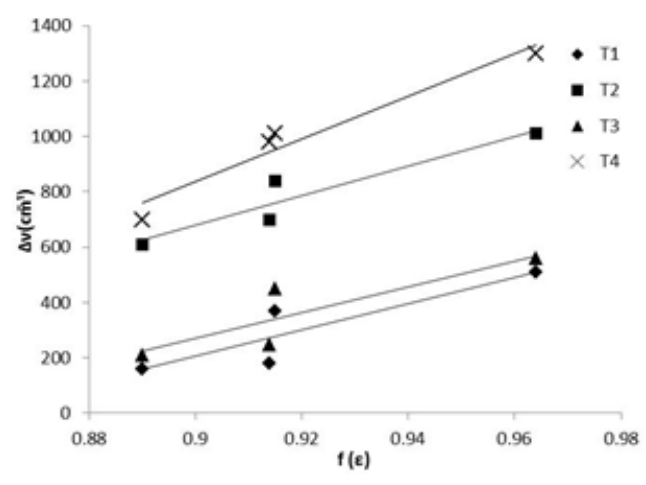

Fig.5 Spectral shifts $\Delta v\left(\mathrm{~cm}^{-1}\right)$ vs. $f(\varepsilon)$

The electric dipole moment of triazolium ylids decreases by excitation, because the internal charge transfer takes place from the ylid carbanion tow ards the ylid heterocycle. So, the intermolecular interactions are stronger in the ground state compared with the excited state. This fact determines spectral shifts to blue in the visible electronic absorption spectra, when passes from the non-polar to polar solvents, or from aprotic to protic ones.

Table 6

GROUND STATE DIPOLE MOMENT $\mu_{g}(D)$; PARAMETERS OF THE LINE (2); R2; MOLECULAR RADIUS A(A), EXCITED STATE DIPOLE MOMENT PROJECTION ON THE GROUND STATE DIPOLE MOMENT

\begin{tabular}{|l|l|l|l|l|l|l|}
\hline Ylid & $\mu_{g}(D)$ & $v_{0}\left(\mathrm{~cm}^{-1}\right)$ & $C_{1}\left(\mathrm{~cm}^{-1}\right)$ & $R^{2}$ & $d . A)$ & $\mu_{e} \cos \varphi(D)$ \\
\hline T1 & 8.25 & 21377 & 4765.5 & 0.79 & 4.924 & 1.321 \\
\hline T2 & 11.42 & 22011 & 5309.6 & 0.89 & 4.978 & 5.724 \\
\hline T3 & 8.82 & 21538 & 4659.3 & 0.76 & 4.993 & 2.290 \\
\hline T4 & 12.60 & 20822 & 7695.8 & 0.95 & 5.089 & 4.606 \\
\hline
\end{tabular}




\section{Conclusions}

Triazolium ylids are zwitterionic compounds with high reactivity and with pharmaceutical importance. Their electric dipole diminishes by excitation.

The visible band of 1,2,4 triazolium ylids shifts to blue when non-polar solvent is replaced by a polar one.

The orientation-induction interactions are predominant in triazolium ylids solutions.

The results obtained in this paper concerning the nature of the intermolecular interactions and of the solvatochromic behavior are important because the triazolium ylids are used in situ for different applications.

\section{References}

1.J OHNSON A W, Ylid Chemistry (1966) Academic Press Inc., New York.

2. ZUGRAVESCU I, PETROVANU M, N-Ylid Chemistry (1976) Ed. Academiei R.S. Romania.

3. DOROHOI D O, PARTENIE H, J Mol Str, 293 (1993) 129-132.

4. POSTOLACHI R, DANAC R, BUURMA N J, Pui A, Balan M, Shova S, Deleanu C, RSC Adv, 3 (2013) 17260-17270.

5. SURPATEANU G G, DELATTRE F, WOISEL P, VERGOTEN G, SURPATEANU G, J Mol Str 645(1), (2003) 29-36.

6.MELNICIUC PUICA N, Sinteze de auxiliari cu structuri polare utilizati in prelucrarea pieilor (Synthesis of auxiliary polar structures used in leather processing) (2007) Ed. Performantica, lasi, Romania.
7.LEGRAND C, ROPA P, VULTURESCU $B$, HOGEA A M, SURPATEANU G $G$, CAZIER F, W OISEL P, SURPATEANU G, Progress in Organic Coating 53(2), (2005) 106-111.

8.BUTNARIU R M, CAPROSU M D, BEJ AN V, UNGUREANU M, POIATA A, TUCHILUS C, FLORESCU M, MANGALAGIU I I, J. Heterocyclic Chem. 44(2007) 1149.

9.BOROWIECKI P, MILNER-KRAWCZYK M, PLENKIEWICZ J, Journal of Organic Chemistry 9, (2013) 516-525.

10.LEACH A R, Molecular modeling. Principles and Applications (2001) Prentice Hall, $2^{\text {nd }}$ ed., Instock.

11.BABUSCA, D., ZELINSCHI, C.B., DOROHOI, D.O., Rev. Chim. (Bucharest), 67, no. 5, 2016, p. 876

12.GHEORGIES, L.V., DIMITRIU, M., FILIP, E., DOROHOI, D.O., Rom. Journ. Phys., 55, no. 1-2, 2010, p. 103-109

13.CLOSCA, V., PUICA-MELNICIUC, N., CLOSCA, M., AVADANEI, I., DOROHOI, D. Ukrainian J ournal of Physics, 63(7), 592. 2018

14.DULCESCU MM, STAN C, DOROHOI DO, REV. CHIM. (Bucharest), 61, Nr. 12, 2010

15.MELNICIUC PUICA N, CLOSCA V, NECHIFOR C D, DOROHOI D O, Rev Roum Chim 59(5), (2014) 359-364

16.*** www.hyperchem.com

17.STEWART J J P, J. Comput. Chem. 10(2), (1989) 209-220.

18.MAFTEI D, ZBANCIOC GH, HUMELNICU I, MANGALAGIU I I, J Phys Chem A, 117(15), (2013), 3165-3175.

19.KOOPMANS T, Physica (Elsevier) 1(1-6) (1934) 104.

20.HURJUI I, IVAN L M, DOROHOI D 0, Spectrochim Acta Mol Biomol Spectrosc, 102, (2013) 219-225.

21. PEARSON R G, Proc Nati Acad Sci USA 83(1986), 8840-8841

$\overline{\text { Manuscript received: } 15.11 .2018}$ 